\title{
Protecting Biodiversity, Traditional Knowledge and Intellectual Property in the Pacific: Issues and Challenges
}

\author{
Kanchana Kariyawasam*
}

\begin{abstract}
The Pacific region contains a vast reservoir of genetic material and traditional knowledge, and it is of the utmost importance that intellectual property rules in the Pacific Islands states support and facilitate the conservation and sustainable use of their unique biological resources. A significant challenge that needs to be addressed in order to promote the effective protection of intellectual property rights of genetic resources is the development of appropriate and adequate legal, institutional, and scientific support systems to deal with the complex issues that instantiate in intellectual property protection. The experience with kava and nonu has highlighted the inadequacy and inequities of existing laws in the region.

This paper examines the issues that are associated with intellectual property protection, the preservation of traditional knowledge and effective access to genetic resources in the Pacific region. Specific reference is made to the situation in Papua New Guinea, Fiji and Vanuatu. The paper provides a brief outline of current systems of intellectual property protection in those countries, particularly those in relation to biodiversity and traditional knowledge. It then addresses the threats posed to indigenous culture and livelihood through biopiracy and explores regionally-based inter-governmental initiatives regarding traditional knowledge that are of common concern through out the region. Finally, it briefly canvasses the ways in which the law should be developed in the region in the future.
\end{abstract}

Lecturer in Law, Department of Accounting, Finance and Economics, Griffith University; Adjunct Research Fellow, The Australian Centre for Intellectual Property in Agriculture, The University of Queensland. 


\section{Background}

The people of the Pacific Islands can be grouped, according to ethnic, cultural and linguistic concepts, into the sub-regions of Melanesia, Micronesia and Polynesia. ${ }^{1}$ The region extends from Japan in the north to New Zealand in the south and Hawaii in the east to the Philippines, Indonesia and Papua New Guinea (PNG) in the far west. The Pacific countries include American Samoa, Australia, Christmas Island, Cocos (Keeling) Islands, Cook Islands, Fiji, French Polynesia, Kiribati, Northern Mariana Islands, Marshall Islands, Micronesia, Nauru, New Caledonia, New Zealand, Niue, Norfolk Island, Papua New Guinea, Pitcairn, Solomon Islands, Tokelau Island, Tonga, Tuvalu, Vanuatu, Wake Island, Wallis and Futuna and Western Samoa. Not only the region but also its constituent countries are culturally diverse. ${ }^{2}$ Most of the countries in the region are developing or least developed.

The Pacific region may be the smallest of all identified regions, but it is, especially Melanesia, a secondary centre of genetic diversity for many indigenous food crops, with much of the diversity in landraces found in farmers' fields. ${ }^{3}$ For example, Papua New Guinea has the second largest diversity of species in the Pacific and it is estimated that approximately 60 per cent of Papua New Guinea's plants are endemic. ${ }^{4}$ The traditional crops of the Pacific include taro, coconut, kava, bananas, yams, sugarcane, breadfruit, fruits and nuts, leafy vegetables and medicinal plants. All countries in the region are directly dependent on plant genetic resources for their livelihoods. For the larger countries like Papua New Guinea, Solomon Islands, Vanuatu, Fiji, Samoa, Tonga, the Cook Islands and French Polynesia, farming is the predominant occupation of rural populations. ${ }^{5}$ By contrast, in the smaller Pacific Island countries and Territories (American Samoa,

1 J C Care, 'Cultures in Conflict: The Role of the Common Law in South Pacific' (2002) 6 Journal of South Pacific Law 1 at 1.

2 For example, 65 vernacular languages are dialects exist in the Solomon Islands alone. In Papua New Guinea, 869 distinct languages are spoken while Vanuatu has 110 languages, see T Newton, 'An Introduction to Policing in the South Pacific Region' (1998) 2 Journal of South Pacific Law, available online: http://www.vanuatu.usp.ac.fj/journal_ splaw/Working_Papers/Newton1.htm; see also Care (note 1 above), p 1.

3 Plant Genetic Resources in the Pacific Towards Regional Cooperation in Conservation and Management, Report Based on an ACIAR -NARI Workshop, Lae, Papua New Guinea, 3-31 March 1999, available online: http:/www.aciar.gov.au/web.nsf/att/JFRN6BN92T/\$file/mn76.pdf (21 June 2007).

4 A Caillaud et al, 'Tabus or not Taboos: How to Use Traditional Environmental Knowledge to Support Sustainable Development of Marine Resources in Melanesia' (2004) 17 SPC Traditional Marine Resource Management and Knowledge Information Bulletin 14 at 28.

5 Agriculture and Forestry, Executory Summary, available online: http://www.pacificplan. org/tiki-download_file.php?fileId=66 (2 March 2007). 
Commonwealth of the Northern Mariana Islands, Federated States of Micronesia, Kiribati, Marshall Islands, Niue, Palau, Pitcairn Island, Tokelau, Tuvalu, and Wallis and Futuna), agriculture is subsistence farming, domestic produce markets do not exist. ${ }^{6}$ Overall, in the majority of Pacific Island countries and territories, agriculture accounts for over 85 per cent of foreign exchange, contributing substantially to 30 to 80 per cent of total employment - representing 20 to 40 per cent of GDP and over 50 per cent of exports.

Given the importance of biological resources in the Pacific, there is a great need for intellectual property protection to safeguard the wealth of biological resources and associated traditional knowledge. This article selects Papua New Guinea, Fiji, and Vanuatu for a case study to review existing and proposed legislation regarding biodiversity, traditional knowledge and intellectual property. It then looks at the region as a whole, focusing on biopiracy, regional governmental initiatives, and regionally developed model laws intended to control the use and exploitation of genetic resources. This article begins by giving a general background of those countries and briefly discusses the role plant genetic resources play and people's dependence upon agriculture. It will then review existing laws, policies, cases and literature. Finally, it looks at ways law could be further developed in the region.

\section{An Overview}

Papua New Guinea, with a land area of 463,000 square kilometres and a population of 5,500,000, is the largest island nation in the Pacific and the richest, in flora and fauna, of all nations in the Pacific. ${ }^{8}$ It probably is home to more than five percent of the world's biodiversity within some of the world's most biologically diverse ecosystems. ${ }^{9}$ The agricultural sector accounts for approximately 25 per cent of the GDP of Papua New Guinea. ${ }^{10}$ Around 85 per cent of the population rely directly on subsistence farming and have little if any contact with the formal economy. ${ }^{11}$ Agriculture is the backbone of its economy, rural households combining subsistence farming with cash crop production.

\footnotetext{
Ibid.

Ibid.

8 S Keu, 'Environment Assessment of Bio-diversity and Projects Development in Papua New Guinea', available online: http://anthropology.uwaterloo.ca/WNB/SKeu\%20 Environmental.html (21 December 2007).

9 S Miller et al, 'Status of biodiversity in Papua New Guinea' (1999), available online: http://www.geocities.com/RainForest/9468/papua_ng.htm (4 September 2007).

10 PNG Chamber of Commerce and Industry, Papua New Guinea Economic Report (2004), available online: http://www.cacci.org.tw/Journal/2004\%20Vol\%201/ PNGcountryReport.pdf (26 November 2007).

11 Ibid.
} 
Fiji has a land area of 18,300 square kilometres and a population of about 880,874 . It has rich biodiversity, and is well-known for high levels of endemism. One family, the Degeneriaceae, is endemic to Fiji, and includes a single tree species, Degeneria Vitiensis, which is of considerable scientific interest because of its unique primitive floral characters. ${ }^{12}$ The indigenous people of Fiji have a unique link with its native flora and fauna in that they are owners and custodians of the biological entities such as Kava. Agriculture is the main economic activity in Fiji, contributing some 43 per cent of foreign exchange earnings, employing half the population. Its large subsistence agricultural sector accounts for around 16 percent of GDP.

Vanuatu has 206,000 people of whom 94 per cent are Melanesian. Vanuatu's economy is primarily agricultural; more than 80 per cent of the population is involved in agriculture ranging from subsistence farming to smallholder farming of coconuts and other cash crops. ${ }^{13}$ Over 80 per cent of Ni-Vanuatu, the Melanesian people in Vanuatu, live in rural areas and mainly depend on subsistence farming. Vanuatu's economy is narrowly-based; services dominate the economy, contributing 72 per cent of GDP, with wholesale and retail trade contributing some 40 per cent. ${ }^{14}$ The economy also relies heavily on agriculture (18 per cent of GDP), ${ }^{15}$ which remains the main focus of the country's development strategy.

\section{Countries' Response to TRIPS and CBD}

The World Trade Organization Agreement on Trade-Related Aspects of Intellectual Property Rights (TRIPS Agreement) is the most relevant WTO agreement in relation to biodiversity, including plant varieties. It is the first international instrument to require member countries to widen the scope of patentability, and requires the introduction of patent protection to new areas such as health and agriculture. ${ }^{16}$ It requires member countries to make patents available for any invention, in all fields of technology without discrimination, subject to the normal tests of novelty, inventiveness (obviousness), and industrial applicability (utility or industrial application). ${ }^{17}$ All member countries must implement the minimum

Biodiversity Hotspots, available online: http://www.biodiversityhotspots.org/xp/hotspots/ polynesia/Pages/biodiversity.aspx (2 January 2008).

Bureau of East Asian and Pacific Affairs October 2007.

14 Virtual Information Center, available online: http://www1.apan-info.net/Portals/45/ VIC_Products/2006/11/061122-P-Vanuatu.doc (23 December 2007).

5 Ibid.

16 P Cullet \& J Raja, 'Intellectual Property Rights and Biodiversity Management: The Case of India' (2004) 4 Global Environmental Politics 97 at 102.

17 Art 27 (1) of the TRIPS Agreement. 
intellectual property standards within a certain period of time. WTO member countries must protect plant varieties, by patents or by an 'effective sui generis system' or a combination of both.

Although a signatory to the TRIPS agreement since 1996, Papua New Guinea has yet to comply with TRIPS obligations. For example, there is no direct provision in the Patent and Industrial Designs Act $2000^{18}$ to protect biological inventions or any living organisms. ${ }^{19}$ Nonetheless, s 13 of the Act has some relevance where it says that an invention would not pass the test of 'novelty' where it can be shown that such an invention is anticipated by 'prior art'. ${ }^{20}$ Accordingly, the Act offers some protection to traditional knowledge. The Papua New Guinean Patent Act 2000 is silent about the patentability of living matter that reproduces itself, that is, patentability of plants, animals and microorganisms. It has not yet implemented either patents or plant breeders' rights to comply with TRIPS obligations.

Fiji's Patent Act (Cap 239) states that invention means any manner of new manufacture and every new process of manufacture and every new method of application of known processes and improvements in any known process. ${ }^{21}$ Nonetheless, the Act contains no provision to protect biological invention or to prevent living organisms from patenting.

In contrast, Vanuatu's Patent Act 2003 explicitly rules out the patentability of living things, including non-living substances occurring in nature, plants and animals. Accordingly, the following are not patentable:

(a) plants or animals other than micro-organisms;

(b) biological processes for the production of plants or animals other than non-biological and micro-biological processes. ${ }^{22}$

It also declares that:

(a) an invention is not patentable if its publication or exploitation would generally be expected to encourage offensive, immoral or anti-social behaviour.

18 Patent and Industrial Designs Act 2000, available online: http://www.ipmenu.com/ archive/PNG-PATENTS-ACT.pdf (4 August 2007).

19 Section 12(2) of the Patent and Industrial Designs Act 2000 states that if the invention is contrary to public order or morality or it is seriously prejudice to the environment it is not patentable.

20 Section 13(2) of the Patent and Industrial Designs Act 2000 explains 'prior art' shall consist of everything disclosed to the public, anywhere in the word by (a) tangible form, (b) oral disclosure, (c) use, or (d) any other way; prior to the filing, or where appropriate, the priority date of the application claming the invention.

21 Fiji Patent Act (Cap 239), s 2.

22 Vanuatu Patents Act of 2003, s 3. 
(b) for the purposes of sub-s (1), behaviour is not offensive, immoral or anti-social only because it is prohibited by a law in force in Vanuatu. ${ }^{23}$

Section 4(1) of the Act states that an invention is taken to be new if it does not form part of the state of the art. State of the art for an invention, 'comprises all matter that, at any time before the priority date of that invention, has been made available to the public, whether in Vanuatu or elsewhere, by written or oral description or by use or in any other way..$^{24}$ Apart from that, the Act has a separate provision on registration of patents involving Indigenous knowledge. According to $s 47$, if the Registrar considers that an application is for the grant of a patent for an invention that is based on, arose out of, or incorporates elements of, indigenous knowledge, ${ }^{25}$ he must refer the application to the National Council of Chiefs. No patent may be granted for an invention that is based on, arose out of, or incorporates elements of, indigenous knowledge unless:

(a) the custom owners of the indigenous knowledge have given their prior informed consent to the grant; and

(b) the applicant and the custom owners have entered into an agreement on the payment by the applicant to the custom owners of an equitable share of the benefits from exploiting the patent.

The patent may be granted without the prior informed consent of the custom owners if the Registrar is, after consultation with the National Council of Chiefs, satisfied that:

(a) the custom owners cannot be identified; or

(b) there is a dispute about ownership of the indigenous knowledge concerned.

However, this patent must not be granted unless the applicant and the National Council of Chiefs have entered into an agreement regarding the payment by the applicant to the National Council of Chiefs of an equitable share of the benefits from exploiting the patent. Any payments made to the National Council of Chiefs must be used for the purposes of indigenous cultural development.

Any patent application involving traditional knowledge must include an

Ibid, s 2(3)(1).

Ibid, s $4(2)$.

25 Section 1 of the Vanuatu Copyright and Related Rights Act of 2000 states that indigenous knowledge means any knowledge that is created, acquired or inspired for traditional economic, spiritual, ritual, narrative, decorative or recreational purposes; and whose nature or use has been transmitted from generation to generation; and that is regarded as pertaining to a particular indigenous person or people in Vanuatu. 
agreement between the applicant and the traditional/customary owners, setting out, inter alia, benefit sharing arrangements. The National Council of Chiefs acts in the absence of the traditional owners and the applicant must consult the Vanuatu National Cultural Council before entering into such an agreement. Both the Council of Chiefs and the National Cultural Council are responsible for the grant of patents, designs and trademarks over indigenous property rights in Vanuatu. If traditional knowledge in Vanuatu is being illegally exploited, the National Cultural Council and the National Council of Chiefs are authorised to institute civil proceedings on behalf of Indigenous peoples in Vanuatu. While Papua New Guinea, Fiji and Vanuatu have agreed to be bound by TRIPS, they have not enacted laws to incorporate the obligations under the Agreement.

The Convention on Biological Diversity (CBD) established the framework rules for access to biological resources providing that states are the legitimate owners of biodiversity and they have sovereign rights to exploit their own resources pursuant to their environmental policies. ${ }^{26}$ It vests sovereignty over natural resources and the right to grant access to genetic resources in national governments giving the State the authority to determine rules for access to its biological resources. ${ }^{27}$ Its main goals are conservation of biological diversity; sustainable use of its components; and fair and equitable sharing of the benefits arising out of the utilisation of genetic resources.

The most important feature of the CBD is that it offers formal international recognition to the central role that indigenous and local communities play in biodiversity conservation, through their traditional and substantial practices and cultural knowledge system. ${ }^{28}$ It recognises both the dependence of local communities on biological resources and the roles that these communities play in the conservation and sustainable use of the resources. According to Art 15(4) of the CBD, access can only occur on mutually agreed terms and with prior informed consent (PIC) of the source state.

Papua New Guinea has not yet complied with its obligation on biodiversity conservation, since it ratified the Convention in 1993. However, there is some limited provision in the following statutes: the Papua New Guinea International Trade (Fauna and Flora) (Amendment) Act 2003, which regulates the exportation and importation of specimens; the Medicines and Cosmetics Act 1999, which regulates the importation of medicinal products, manufacture, sale and supply of medicinal products, devices and cosmetics through the licensing processes;

${ }^{26}$ Convention on Biological Diversity Art 3.

27 According to Art 3 of the CBD, states have, in accordance with the Charter of the United Nations and the principles of international law, the sovereign right to exploit their own resources pursuant to their own environmental policies, and the responsibility to ensure that activities within their jurisdiction or control do not cause damage to the environment of other states or of areas beyond the limits of national jurisdiction.

${ }^{28}$ Art $8(\mathrm{j})$ of the CBD relates to the respect, preservation and maintenance of knowledge, innovation and practices of indigenous and local communities, according to the CBD. 
the Quarantine and Inspection Authority Act, which establishes the national agriculture, quarantine and inspection authority, and focuses on biosecurity; the Customs Act (Consolidated to No 44 of 2000), which provides for the control of exports, particularly of prohibited exports; the Customs (Prohibited Export) Regulation (Consolidated to No 23 of 1992) which contains a list of items which are restricted and prohibited from export; the Customs Act (Consolidated to No 41 of 2000), which provides for the control of both imports and exports; and the Environment Act 2000, which is designed to protect the environment, the ecological system, biodiversity and the control of impacts on the environment. These laws are intended to protect plant genetic resources for several reasons from illegal export. ${ }^{29}$

Fiji which ratified the CBD in 1992 drafted a Sustainable Development Bill in 1996 to restrict bioprospecting to any activity undertaken to harvest or exploit biological resources for commercial purposes including investigative research and sampling. ${ }^{30}$ The Bill outlines a general permission process for biological-diversity prospecting in Art 249, including the requirement of public notification and export controls. According to the Draft, bioprospecting is prohibited without prior informed consent. Benefit-sharing is covered in Art 249(1)(c), which requires that 'a fair return is provided for any commercial exploitation of Fiji's biological resources'. ${ }^{31}$ This draft legislation aims to control the process of granting access for persons wishing to conduct biodiversity research to ensure that no ecological, social or economic harm is caused by the biological research or exploitation; taking a biological sample does not have an undesirable impact on Fiji's biodiversity; a fair return is provided for commercial exploitation of Fiji's biological resources; and prior informed consent from the resource owners is obtained before any collection can take place. ${ }^{32}$

Vanuatu ratified the Convention on Biological Diversity in 1992 and affirmed its sovereign right over its biological and genetic resources. The Vanuatu Environment Management and Conservation Act 2000 Act regulates bioprospecting, defining bioprospecting as including harvesting or exploiting samples of genetic resources, samples of any derivatives of genetic resources, the knowledge, innovations, and customary practices of local communities associated with those genetic resources, for the purpose of research and product development, including investigative research and sampling but not including customary uses of genetic resources. New Guinea, (Asia-Pacific Press, Canberra, 2000) p 129.

30 Convention on Biological Diversity, UNEP/CBD/COP/3/20 - Conference of the Parties to the Convention on Biological Diversity, Third meeting, Buenos Aires, Argentina, 4 to 15 November 1996.

31 Ibid.

32 The Vanuatu Environment Management and Conservation Act 2000, s 2. 
Any person wishing to exploit and/or research traditional biodiversity knowledge must apply for a permit from the Biodiversity Advisory Council. ${ }^{33}$ The Council has to be satisfied that a legally binding and enforceable contract is concluded with customary landowners, or any owner of the traditional knowledge. The contract has to specify certain matters such as (a) rights of access (b) rights of acquisition of any biological resources or traditional knowledge (c) appropriate fees, and (d) concessions or royalties in relation to the activity undertaken. ${ }^{34} \mathrm{~A}$ bioprospecting permit is necessary for those who are planning to undertake or attempt to undertake any biodiversity prospecting; or export or attempt to export any specimen obtained from biodiversity prospecting; or import or attempt to import any foreign organism that may have a significant adverse impact on Vanuatu's native flora or fauna; or contravene any law relating to the protection of Vanuatu's native flora and fauna.

In addition, the Vanuatu Constitution gives clear recognition to the rights and interests of traditional landholders, who remain the principal managers and users of biological resources and systems. There are two provisions in the Vanuatu Constitution to protect biological resources against commercial exploitation:

(a) all land in the country is held following traditional systems of land tenure and therefore all biological and genetic resources are owned according to traditional customary systems. In this context, the role of the state should be to provide the overall framework to regulate access, and

(b) all genetic resources (marine and terrestrial) belong to the state. All activities concerning access must be undertaken at the national level but if benefits are derived from the use of biological or genetic resources then a percentage of these must be granted to the local community, and land owners who claim ownership of the resources. ${ }^{35}$

Articles 29 and 30 of the Constitution discuss the National Council of Chiefs' role in the protection and preservation of Vanuatu's culture and traditions. According to Art 95, customary laws are equivalent to other Vanuatu laws.

The cumulative effect of these international obligations is to make it mandatory for governments to enact laws recognising intellectual property rights in biological resources, including indigenous and local community knowledge. Most countries

33 The Vanuatu Environment Management and Conservation Act 2000, s 33(3). The Council is responsible for advising the Minister, through the Chairperson, on any matter relating to the implementation of the Convention on Biological Diversity and, in particular, on matters relating to commercial bioprospecting.

34 The Vanuatu Environment Management and Conservation Act 2000, s 34(6)(a).

35 Report on Access to Genetic Resources and Benefit-Sharing (ABS) - National Workshop (19-20 April 2001), available online: http://www.field.org.uk/files/vanuatu.pdf (18 July 2007). 
in the Pacific region are yet to recognise and affirm the primacy of international obligations in the area of patents, plant breeders' rights and access over biological resources and traditional knowledge. Protecting genetic resources is one of the major issues in the region, needing to be addressed by intellectual property law, especially to comply with their international obligations.

\section{Threats to Indigenous Knowledge: Case Studies in the Pacific Region}

This section highlights the scientific and commercial exploitation of the Pacific region's biological resources and associated knowledge in the development of drugs and related pharmaceutical products. It also describes the progress made in identifying and analysing patent applications and patents concerning inventions obtained or developed through the use of Pacific biological resources without the consent of their owners or without payment of compensation. Some of the examples given below illustrate the products that have been developed using traditional knowledge in the Pacific region.

Kava (Piper Mythesticum) plant is an important cash crop native to many Pacific Ocean islands where it is highly valued as the source of the ceremonial beverage. This plant is grown in Fiji, Vanuatu, the Federated States of Micronesia, Samoa, Hawaii, French Polynesia, Tonga, and Wallis and Futuna. Studies suggest that kava directly influences the limbic system, the ancient part of the brain associated with emotions and other brain activities. ${ }^{36}$ Kava has been employed in European phytotherapy for many years for the treatment of various disorders, including urinary tract infections, anxiety, menopause and as a muscular relaxant. ${ }^{37}$ This plant is subject to the several patents.

(a) Two German companies, William Schwabe and Krewel-Werke, have patented kava as a prescription drug for treating strokes, insomnia, and Alzheimer's disease;

(b) In the USA, kava has been approved as a dietary supplement and many large companies are now promoting kava for its anti-stress and tranquilising effects. Kava generated \$30 million in 1997 on the US market alone. $^{38}$

36 Herbal Information, available online: http://www.holisticonline.com/Herbal-Med/_ Herbs/h24.htm (10 November 2007).

37 V Schulz et al, Rational Phytotherapy ( $4^{\text {th }}$ ed, Springer-Verlag, Berlin, 2001).

38 G Stenton, 'Biopiracy within the Pharmaceutical Industry: A Stark Illustration of Just How Abusive, Manipulative and Perverse the Patenting Process can be Towards Countries of the South' (2003) 1 Hertfordshire Law Journal 30 at 32. 
(c) The well-known French company, L'Oreal has patented the use of kava to reduce hair loss and to stimulate hair growth. It is estimated that L'Oreal earns US $\$ 10$ billion a year in sales.

Ngali nut and its products have been developed over thousands of years by the rural people of the Solomon Islands and their Melanesian neighbours. ${ }^{40}$ Research on Ngali by pharmaceutical companies led to the development of drugs for treating several diseases. ${ }^{41}$ It has been found that an extract of Ngali nut can be effective in treating a broad range of diseases such as cancer, infection, arthritis, asthma, hypertension, and pain. ${ }^{42}$ An Australian entrepreneur has patented nut oils as a treatment for arthritis pain. ${ }^{43}$ The equivalent patent application succeeded in the USA and the US patent and trademark office (USPTO) has granted three patent rights (numbers 6,410,596, 6,541,522 and 6,542,511) to Insmed Inc for its 'novel invention of pigeon pea extracts' for treating diabetes, hypoglycaemia, obesity and atherosclerotic, cardiovascular disease (clogged arteries).

The Nonu plant (Indian Mulberry - Morinda Citrifolia) has been cultivated in the region for 2000 years and is used as a source of food and medicine in the Pacific region. The various parts of the fruit are used for different diseases; for example parts of the fruit are used as a tonic and to contain fever; the leaves, flowers, fruit, and bark can treat eye problems, skin wounds and abscesses, gum and throat problems, respiratory ailments, constipation, and fever, stomach pains; heated leaves applied to the chest relieve coughs, nausea, and colic; and juice of the leaves is taken for arthritis. ${ }^{45}$ The fruit juice is in high demand in alternative medicine for different kinds of illness such as arthritis, diabetes, high blood pressure, muscular aches and pains, menstrual difficulties, headaches, heart diseases, AIDS, cancers, gastric ulcers, sprains, mental depression, senility, poor digestion, atherosclerosis, blood vessel problems and drug addiction. ${ }^{46}$ In 1995 , Nonu Samoa Enterprise began exporting of Nonu to the US and patent rights

39 C Harrington, 'Globalisation for Natural for the Pacific, But Women Will Have to Learn to Negotiate', Pacific Magazine (2002).

40 'Attempt for Ngali Nut Patent Condemned' (2003), available online: http://www.lifhaus. com/archive/dec2103.htm (21 February 2006).

41 The Financial Express, 4 August 2003; quoted in Intellectual Property Rights (2003) available online: http://www.tifac.org.in/do/pfc/pub/july03.pdf (24 February 2006).

42 W Whistler, Tongan Herbal Medicine, Isle Botanica, Honolulu, Hawaii, 1992, p 89-90; quoted in MY Wang et al, 'Morinda Citrifolia (Noni): A Literature Review and Recent Advances in Noni Research' (2002) 23 Acts Pharmacol Sin 1127 at 1128.

43 Queenslander Peter Hull has been granted a United States patent on Canarium nut oil (\#6,395,313, 28 May 2002).

44 Ibid.

45 A Hirazumi et al, 'Immunomodulation Contributes to the Anticancer Activity of Morinda Citrifolia (Noni) Fruit Juice' (1996) 39 Proc West Pharmacol Soc1 at 7-9.

46 MY Wang et al, 'Morinda Citrifolia (Noni): A Literature Review and Recent Advances in Noni Research' (2002) 23 Acts Pharmacol Sin 1127 at 1128. 
have been granted in both the US and Europe. ${ }^{47}$

In addition, the Samoa mamala tree, Homalanthus Nutans, was traditionally used by Samoan people to treat conditions such as hepatitis, back pain, diarrhoea, and yellow fever. The US National Cancer Institute (USNCI) developed a drug from the plant that could potentially be used to treat HIV; it is also developing a drug for treating viral infections. ${ }^{48}$ The patent rights of the mamala tree belong to the US Department of Health and Human Services, the US Army, and Brigham Young University; the technology has been licensed to the AIDS Research Alliance (ARA). ${ }^{4}$

Not only have the regional biological resources been subject to patent applications, but the region's human genes have also been exploited for commercial purposes by multinational companies. For example, the Papua New Guinean government is concerned about the patenting of a cell-line derived from a member of the Hagahai population. The Hagahai cells, which were developed from a blood sample from a member of the Hagahai tribe, were potentially valuable in diagnostic tests and vaccination for leukaemia and related diseases. The first Hagahai cells patent application was filed on 24 August 1990 by the US National Institutes of Health (NIH) and the product is described as (US Patent No 5,397,696) "Papua New Guinea human T-lymphotropic virus". ${ }^{1}$ One of the researchers named as an inventor in this patent responded to the PNG government objections regarding the patent claim saying that there was nothing in his employment contract obliging him to assign patent rights to the government. ${ }^{52}$

Even though this invention is worth millions of dollars, under the patent system there are no benefits for the owners of the original indigenous cells from which the patented cells have been developed. ${ }^{53}$ However, after a public protest,

Grain, 'Traditional Knowledge of Biodiversity in Asia-Pacific: Problems of Piracy \& Protection' (2002), available online: http://www.grain.org/briefings/?id=97 (2 January 2008).

48 K Perry, 'Getting Fair Price for Indigenous Remedies' (2000) The Guardian, available online: http://www.guardian.co.uk/appeal2000/story/0,7369,414139,00.html\#article_ continue (21 January 2008).

49 Etc Group, 'Are Patents Out of Control? Human Rights and Predatory Patents... The Right to Say "No", available online: http://www.etcgroup.org/en/take_action/past_ actions.html (24 October 2007).

50 Rafi Communiqué, 'New Questions about Management and Exchange of Human Tissue at NIH/ Indigenous Person's Cells Patented' (1996), available online: http://www.cptech. org/ip/rafi.html (21 March 2007).

51 Ibid.

52 Ibid.

53 One commentator argues that 'the original donor of cells used to develop a cell line cannot claim to be an inventor under patent law, since he or she usually has no conception of the potential of those cells and will pay no technical part in the development of a useful product', see S C Jong, \& R H Cypress., 'Managing Genetic Material to Protect Intellectual Property Rights' (1998) Journal of Industrial Microbiology and Biotechnology 95 at 96. 
NIH abandoned this patent. ${ }^{54}$

The Solomon Islands has experienced a similar gene patent claim where the $\mathrm{NIH}$ has applied for a patent on cells from people from the Solomon Islands. These cell lines could be useful in producing vaccines and/or diagnosing human T-lymphotropic virus type I. ${ }^{55}$ Once again, this patent application was made without the prior informed consent of either Government or the local community. In response to the government's request for the withdrawal of the application, the US Ambassador to the Solomon Islands, stated that 'there is no provision for considerations related to the source of the cells that may be the subject of a patent application. ${ }^{56}$ According to the existing patent law, it is of no legal concern how the genetic samples were obtained. ${ }^{57}$ It is claimed that the US government eventually withdrew the patent application, but has not returned the materials concerned. $^{58}$

Another case was also reported from Tonga, in which an Australian Biotechnology Company, Autogen, signed an agreement in November 2000 with the Tongan Ministry of Health to establish a research project aimed at 'identifying genes that cause common diseases using the unique population resources in the Kingdom of Tonga'. ${ }^{59}$ Due to adverse public reaction in Tonga, Autogen is reported to have withdrawn its interest in August 2001. However, other biotechnology companies are interested in the Tongan people because they are genetically isolated.

These examples highlight the fact that the Pacific plant genetic resources and associated traditional knowledge in medicinal plants have been subject to worldwide interest in the development of new drugs in the biopharmaceutical industry. Over the past few decades, under the impact of the commercialisation of biodiversity, the unauthorised use of, and access to, genetic resources and increased numbers of patents granted upon their genetic resources have become common problems in the region.

54 M Forsyth, 'Cargo Cults and Intellectual Property in the South Pacific' (2003) 14 Australian Intellectual Property Journal 193 at 200.

55 L Senituli, 'Ngeia 'o e Tangata - It's about Human Dignity, Stupid' available online: http://classshares.student.usp.ac.f/DG401/coe-article-lopeti.doc (22 September 2007).

56 D Harry, 'Patenting of Life and Its Implications for Indigenous Peoples' (1995) available online: http://user.uni-frankfurt.de/ - ecstein/gen/iatp/ipr-info7.html (3 January 2008).

57 Ibid.

58 PD Roughan, 'The Diversity Resource? Genetic Research in Pacific Island Futures' available online: http://devnet.anu.edu.au/online\%20versions\%20 pdfs/60/1960Roughan.pdf (1 April 2007).

59 B Burton, 'Opposition Stalls Genetic Profiling Plan for Tonga' Inter Press Service/Asia Times Online, available online: http://pidp.eastwestcenter.org/pireport/graphics.shtml, quoted in M Forsyth, 'Cargo Cults and Intellectual Property in the South Pacific' (2003) 14 Australian Intellectual Property Journal 193 at 200. 


\section{Model Laws in the Pacific Region}

In addition to the above governmental initiatives, the region has attempted to develop regional model laws with the aim of regulating access to biological resources and community knowledge. The Pacific region currently has two mechanisms that seek to assist Pacific Island countries and territories to legally protect their traditional knowledge and cultural expressions, based upon respect for customary law and practice. They are as follows.

\section{The Model Law for the Protection of Traditional Knowledge and Expressions of Culture, $2000^{60}$}

This model law would provide protection to the traditional cultural rights that exist in traditional knowledge and expressions of culture whether they are in material form or not. ${ }^{61}$ Part 4 of the Model Law provides that a prospective user of traditional knowledge and expressions of culture can seek the prior informed consent from either the Cultural Authority or directly from the owners of the knowledge ${ }^{62}$ where the prior informed consent is to be evidenced in the form of an 'authorised user agreement'. ${ }^{63}$ If an authorised user agreement exists between the prospective user and the traditional owners it appears that the traditional owners are deemed to have given their prior informed consent to the proposed use. $^{64}$

If the traditional owners cannot be identified or if there is a dispute about ownership, customary law and practice must be applied to the concerned matter. ${ }^{65}$ The Cultural Authority is the traditional owner of the traditional knowledge or expression of culture if the owners cannot be identified and any benefit derived from that agreement must be used for traditional cultural development purposes. ${ }^{66}$

The Model Law for the Protection of Traditional Knowledge and Expressions of Culture, 2000 at http://www.grain.org/brl/?docid=698\&lawid=1430 (21 April 2008).

$61 \mathrm{Cl} 8$ of the Model Law.

${ }^{62} \mathrm{Cl} 25$ provides that if a prospective user directly deals with traditional owners, he or she must: (a) advise the Cultural Authority that he or she sought the prior informed consent of the traditional owners; (b) provide the Cultural Authority with a copy of the authorised user agreement between the prospective user and the traditional owners for comment and advice about other traditional owners. This requirement cannot be contracted away. Further, if a copy of the agreement is not provided to the Cultural Authority, cl 25(6) renders the agreement null and void; and (c) provide the Cultural Authority with a copy of the signed authorised user agreement, for entry in the register within 28 days after the agreement comes into force.

63 Part 4 of the Model Law.

${ }^{64} \mathrm{Cl} 23(1)$ of the Model Law.

$65 \mathrm{Cl} 18$ of the Model Law.

66 Sub-cll 19(1) \& (2) of the Model Law. 
This Model Law also provides for moral rights of authors, which are the right of attribution, the right against false attribution and the right against derogatory treatment in respect of traditional knowledge and expressions of culture. ${ }^{67}$

\section{The Model Law on Traditional Ecological Knowledge and Innovations and Practices, $2000^{68}$}

The purpose of this model law is to prevent the unauthorised use of traditional ecological knowledge, innovations and practices, and to ensure equitable sharing of benefits derived from the use of such knowledge, innovations and practices. The model law encompasses not only knowledge, but also products (such as innovations ${ }^{69}$ ) and practices based on that knowledge. Any person who is seeking to use traditional ecological knowledge or an innovation, or any part of such innovation, or practice for commercial use ${ }^{70}$ must receive the prior informed consent of the owner or owners of the knowledge. ${ }^{71}$ The user of the knowledge must also enter into an access and benefit sharing agreement with the owner or co-owners. ${ }^{72}$ All traditional ecological knowledge may be registered in a national registry and if the knowledge is owned by two or more countries or by the Pacific region as a whole, the regional register can be employed for the registration. ${ }^{73}$

These Model Laws have no legal significance because they have not been

67 Part 3 of the Model Law for the Protection of Traditional Knowledge and Expressions of Culture (2002).

68 According to Art 2 of the Model Law, traditional ecological knowledge means generations-old knowledge whether embodied in tangible form or not, gained over generations of living in close contact with nature regarding: (a) living things, their constituent parts, their life cycles, behaviour and functions, their effects on and interactions with other living things (including humans) and with their physical environment; (b) the physical environment including water, soils, cereals, weather and lunar effects, processes and cycles; (c) the obtaining and utilising of living or non-living things for the purpose of maintaining, facilitating or improving human life; see: http:// www.grain.org/brl_files/brl-model-law-pacific-en.pdf (21 April 2008).

69 Innovation means biological material - defined as any part, including the genes, of a plant, animal or microorganism - rendered of any or of enhanced use or value through the application of traditional ecological knowledge.

70 Commercial use occurs when traditional knowledge ecological knowledge, or an innovation or practice, becomes the subject of a commercial transactions - commercial transaction is a deliberately wide and covers transactions such as sales, leases, licenses, mortgages, conditional sales etc.

71 Section 10 of the Model Law.

72 Ibid.

73 Art 9 of the Model Law. Accordingly, each national government in respect of a national register, and the Regional Coordinator in respect of a regional register, must put in place rules to establish and maintain a register and to provide for confidentially. 
adopted by any state in the Pacific region. ${ }^{74}$ Persuading states to adopt these Model laws has been challenging.

\section{Conclusion and Recommendations}

The Pacific is an attractive region for bioprospecting because of its rich biodiversity. Despite its biological diversity and richness, existing laws are inadequate and ineffective. In order to achieve adequate protection for intellectual property rights over biological resources, a set of national and regional rules and procedures must be established in line with international commitments. Such measures should aim to include:

(a) developing national policies and laws on the protection, conservation, preservation and sustainable use of genetic resources in accordance with national interest;

(b) reviewing existing policies, strategies, and laws, and application of customary and contract laws in order to develop their own strategies;

(c) promoting appropriate access to genetic resources, and the fair and equitable sharing of benefits arising from the utilisation of the country's resources;

(d) creating a competent national authority responsible for the regulation, monitoring and coordination of developmental activities;

(e) enforcing the rights of breeders and local communities, including farming communities;

(f) developing negotiation skills among all stakeholders;

(g) disseminating information, expertise, and facilities at national level; and

(h) promoting greater awareness of the need for biodiversity inventory and ecosystem conservation in the region.

74 'Countries wishing to enact the Model Law are free to adopt and/or adapt the provisions in accordance with national needs, the wishes of their traditional communities, and their legal drafting traditions. Matters of detail or implementation are left to be determined by national laws and systems. The Model law is envisioned as a starting point, and will be modified based on the experiences of member countries in enacting and administering their own laws, and in accordance with further international developments': R Griffiths, 'Protection and Promotion of Culture in the Pacific', available online: http://europa. eu.int/comm/development/body/publications/courier/courier194/en/en_064.pdf (21 March 2007). 
These countries must adopt a biodiversity management regulatory framework across the region to optimise the utilisation of biological resources. Member countries must adopt a consistent policy on access to and benefit-sharing from the region's biological base. There is an increasing need for regional cooperation among nations in the Pacific to conserve biodiversity, achieve sustainable use, and promote equitable benefit-sharing, especially through an appropriate regional model. This cooperation would enable the nations of the region to recognise the common problems they face and to develop strategies that would facilitate common solutions for shared problems. In view of that, it may be said that regional integration provides an excellent opportunity for achieving regional collaboration; harmonising policies; and synchronising interventions across borders. Such a mechanism is more likely to succeed in the states with a similar culture, economy, and ecology. 